Katarina Maksimović

Research Associate City Administration of the City of Belgrade, Belgrade

Mirko Maksimović Research Assistant Belgrade Waterworks and Sewerage, Kneza Miloša 27, Belgrade

Ivana Vasović Maksimović

Research Assistant Lola Institute, Kneza Višeslava 70a Belgrade

Boško Rašuo

Full Professor University of Belgrade Faculty of Mechanical Engineering

Stevan Maksimović Full professor Military Technical Institute, Belgrade

\section{Postbuckling and Failure Analysis of Layered Composite Panels}

This work consideres the buckling and postbuckling behaviour of axially compressed layered composite panels including initial failure analysis. For determination stresses in layered composite panels Finite Element Method (FEM) used. A series of experiments were conducted to verify the FEA-results, but also to address the stability and strength of the composite structure. Combining a geometric nonlinear finite element analysis (FEA) based on the von Karman theory and High Order Shear Deformation Theory (HOST) are used to study the first-ply failure behavior as well as the postbuckling behavior of laminated type composite panels. For this purpose and for the investigation of the failure responses improved 4-node layered shell finite elements are used. The finite element formulation is based on the third order shear deformation theory with four-node shell finite elements having eight degres of freedom per node. A simple method is proposed to predict buckling loads and the post-buckling behaviour together with initial failure analysis of layered composite panels. The experiments carried out on SCHRENK system. Comparisons between numerical and experimental results show quite a good agreement.

Keywords: Postbuckling analysis, Laminated composite panels, Initial failure analysis, Finite Element Analysis (FEA).

\section{INTRODUCTION}

Due to their high specific properties, the use of fiberreinforced composites has increased drastically during the past few years in a large range of industrial applications. However, in order to meet the aspirations of aeronautical companies for lighter, safer and less polluting planes, the next generations of aircraft will integrate more and more composite components.

The composite layered panels with fibers are the most usually used in aerospace industry and in engineering constructions as well. Aircraft structure panels are subjected to any combination of in plane, out of plane and shear loads during application. Due to the geometry and general load of the aircraft hull, buckling is one of the most important failure criteria of these structures.

This is why it is necessary to develop the appropriate methodologies able to correctly predict the behavior of a laminated composite plate in the deep postbuckling region, at the collapse load, which is characterized by separation between the skin and the stiffeners, delaminations, crack propagations and matrix failure, as well as to understand its behavior under repeated buckling.

Fibre-reinforced composite laminates are materials with high specific as well as absolute stiffness and strength and therefore are promising alternatives to conventional structural materials [1-4]. Availability of reliable computational techniques for prediction of

Received: December 2019, Accepted: February 2020

Correspondence to: Prof Stevan Maksimović

Military Technical Institute, Ratka Resanovića 1,

11132 Belgrade, Serbia

E-mail: s.maksimovic@mts.rs

doi:10.5937/fme2002447M

(C) Faculty of Mechanical Engineering, Belgrade. All rights reserved stiffness and stability would be a major contribution to improved quality assessment of preliminary design, as well as to saving by replacement or at least reduction of the number of tests required for qualification. Nowadays modern computational facilities, with the enormously increased computer capabilities, offer the opportunity to investigate the complex buckling phenomena with robust nonlinear numerical analysis [5-8]. Numerous numerical solutions based in shell finite elements had been continuously developed for the analysis of layered composite structures. Formulation of the shell finite elements based on classical laminate plate theory (CLPT) is inadequate. Laminated plates/shells made of advanced filamentary composite materials, whose elastic to shear modulus ratios are very large, are susceptible to thickness effects because effective transverse shear module are significantly smaller than the effective elastic module along fiber directions. These high ratios of elastic to shear modulus render the classical laminated plate theory inadequate for the analysis of thick composite plates. Higher order shear deformation theory (HOST) with imposed condition on vanishing of the surfaced shear stresses is needed for laminated anisotropic shells $[9,10]$. In the present work a quadrilateral isoparametric shell finite element is developed based on combining HOST $[11,12]$ and membrane elements with drilling/rotational degrees of freedom (DOF) [13-23]. Membrane elements with drilling DOF are of particular importance as they form the building block of shell facets with full rotational DOFs.

This paper covers the experimental verification of the predictive capabilities of such Finite Element Analysis (FEA). For these principal investigations a representative substructure of the axially compressed composite panels are considered. The problem statement, ex- 
perimental setup, FE-modelling as well as the presentation and discussion of results are outlined [24,25]. Subsequently, some experimental results concerning aspects of stability and strength are also presented.

\section{HIGHER ORDER SHEAR DEFORMATION THEORY}

The higher-order shear deformation theory used here [5], takes into account the parabolic distribution of transverse shear stress along the laminate thickness. This requires the use of a displacement field in which the inplane displacements are cubic functions of the thickness coordinate and the transverse deflection in constant along the plate thickness. This definition of the displacement field satisfies the condition that the transverse shear stress be zero on the plate surface and not zero in any other place. So that the displacement field is given by

$$
\begin{aligned}
& u_{1}(x, y, z)=u(x, y)+z \\
& \psi_{x}(x, y)+z^{2} \xi_{x}(x, y)+z^{3} \zeta_{x}(x, y) \\
& u_{2}(x, y, z)=v(x, y)+z \psi_{y}(x, y)+z^{2} \xi_{y}(x, y)+z^{3} \zeta_{y}(x, y) \\
& u_{3}(x, y, z)=w(x, y)
\end{aligned}
$$

where $\mathrm{u}, \mathrm{v}$ and $\mathrm{w}$ are the displacements of a point $(\mathrm{x}, \mathrm{y})$ of the midplane and $\psi_{\mathrm{x}}, \psi_{\mathrm{y}}$ are the rotations of the normals to the midplane about the axis $\mathrm{x}$ and $\mathrm{y}$, respectively. The functions $\xi_{\mathrm{x}}, \xi_{\mathrm{y}}$ and $\zeta_{\mathrm{x}}$, $\zeta_{\mathrm{y}}$ are determined by using the condition that the transverse shear stresses $\sigma_{4}$ and $\sigma_{5}$ are zero on the plate surfaces

$$
\begin{aligned}
& \tau_{x z}=\sigma_{5}\left(x, y, \pm \frac{h}{2}\right)=0 \\
& \tau_{y z}=\sigma_{4}\left(x, y, \pm \frac{h}{2}\right)=0
\end{aligned}
$$

For orthotropic plates or plates laminated in orthotropic layers, these conditions are equivalent to the requirement that the corresponding strains be zero on these surfaces

$$
\begin{aligned}
& \varepsilon_{5}=\Psi_{x}(x, y)+2 z \xi_{x}(x, y)+3 z^{2} \zeta_{x}+\frac{\partial w}{\partial x} \\
& \varepsilon_{4}=\Psi_{y}(x, y)+2 z \xi_{y}(x, y)+3 z^{2} \zeta_{y}+\frac{\partial w}{\partial y}
\end{aligned}
$$

Taking into account that $\varepsilon_{4}$ and $\varepsilon_{5}$ are zero on the plate surfaces, the following expressions are obtained

$$
\begin{aligned}
& \xi_{y}=0, \xi_{y}=0 \\
& \zeta_{x}=-\frac{4}{3 h^{2}}\left(w_{, x}+\Psi_{x}\right), \zeta_{y}=-\frac{4}{3 h^{2}}\left(w_{, y}+\Psi_{y}\right)
\end{aligned}
$$

Introducing eqn (4) into eqn (1), the displacement field becomes

$$
\begin{aligned}
& u_{1}=u+z\left[\Psi_{x}-\frac{4}{3}\left(\frac{z}{h}\right)^{2}\left(w_{, x}+\Psi_{x}\right)\right] \\
& u_{2}=v+z\left[\Psi_{y}-\frac{4}{3}\left(\frac{z}{h}\right)^{2}\left(w_{, y}+\Psi_{y}\right)\right] \\
& u_{3}=w
\end{aligned}
$$

The displacement field (5) accommodates quadratic variation of transverse shear strains and vanishing of transverse shear stresses on the top and bottom of a general laminate composed of orthotropic layers. The HOST provides a slight increase in accuracy relative to the first order shear deformation theory solution at expense of a significant increase in computational effort. Thus there is no need to use shear correction factors in a higher order theory. The Equation (5) can be adapted in the next form

$$
\begin{aligned}
& u_{1}=u+z\left[-\alpha \frac{\partial w}{\partial x}+\beta \Psi_{x}-\lambda \frac{4}{3}\left(\frac{z}{h}\right)^{2}\left(w_{, x}+\Psi_{x}\right)\right] \\
& u_{2}=v+z\left[-\alpha \frac{\partial w}{\partial y}+\beta \Psi_{y}-\lambda \frac{4}{3}\left(\frac{z}{h}\right)^{2}\left(w_{, y}+\Psi_{y}\right)\right] \\
& u_{3}=w
\end{aligned}
$$

Equation (6) can be used for all plate theories: classical plate theory $(\alpha=1, \beta=0$ i $\lambda=0)$, first order shear deformation theory $(\alpha=0, \beta=1$ i $\lambda=0)$ and for HOST $(\alpha=0, \beta=1$ i $\lambda=1)$.

\section{FINITE ELEMENT ANALYSIS}

Finite element analysis (FEA) is employed to investigate the buckling and postbuckling behaviour of composite panels under axial compression. The 4-node shell finite elements [5,11] are used in this investgation. These elements present eight degress of freedom at each node: three translations, three rotations about the nodal $x, y$ and $z$ axes and two higher order terms.

Based on the higher order shear deformation plate theory in the present analysis, a four-noded quadrilateral element (Q4-RT) with 8 degrees of freedom per node $[5,11]$ is used. The formulation of a 4-nodes shell finite element that can be good enough also if applied to the thin multilayered plates/shells is by no means an easy matter. The author's experience has shown that a good approach to the formulation of a 4-node shell finite element can be based on the application of the Discrete Kirchhoff's Theory (DKT) [11] for bending behavior. DKT ensures $C^{1}$ continuity at discrete points on inter-element boundaries. The improved 4-noded layered shell element is derived combining HOST and DKT, Fig.1.

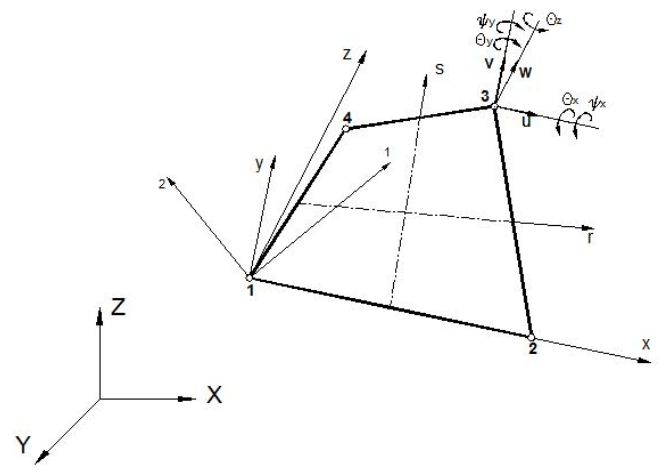

Figure 1. Description of 4-noded shell finite element

More details about that element can be found in [9] and [14]. In the $\mathrm{C}^{\mathrm{o}}$ finite element theory the continuum displacement vector within the element is defined by 


$$
a=\sum_{i=1}^{M} N_{i}(r, s) a_{i}
$$

where $N_{i}(r, s)$ is the interpolation function associated with the node $i$ and expressed through the normalized coordinates (r, s); $M$ is the number of nodes in the element and $a_{i}$ is the generalized displacement vector in the mid-surface. In the case of the negligible midsurface normal stress $\sigma_{\mathrm{z}}$ the stress-displacement relationships, stress resultants and the constitutive equations associated with the higher-order shear deformation theory are given in [5] and [14]. The total stiffness matrix of the element is obtained by the linear superposition of the following three independent parts:
i. Membrane stiffness matrix $K_{M}$
ii. Bending stiffness matrix $K_{B}$, and
iii. Rotational stiffness matrix $K_{\Theta z}$

Four-node quadrilateral layered shell element, for geometrical nonlinear analysis, is derived combining a higher order shear deformation theory and membrane elements with drilling/rotational degrees of freedom. This finite element has 8 degrees of freedom (DOF) per node

$$
\mathrm{a}^{\mathrm{T}}=\left(\mathrm{u}_{0}, \mathrm{v}_{0}, \mathrm{w}_{0}, \mathrm{v}_{\mathrm{x}}, \mathrm{v}_{\mathrm{y}}, \mathrm{v}_{\mathrm{z}}, \chi_{\mathrm{x}}, \chi_{\mathrm{y}}\right)
$$

where $\mathrm{u}_{0}, \mathrm{v}_{0}, \mathrm{w}_{0}, \mathrm{v}_{\mathrm{x}}, \mathrm{v}_{\mathrm{y}}$ represent conventional degrees of freedom, $v_{z}$ are in-plane vertex rotations. The terms $\chi_{\mathrm{x}}$ and $\chi_{\mathrm{y}}$ are the corresponding higher order terms in the Taylor's series expansion used in the theory and are also defined at the reference plane. This element is obtained by superposition of the refined membrane element with rotational degrees of freedom and discrete Kirchhoff model for bending.

In order to avoid singularity in the assembled matrix using flat elements in a global coordinate system here is used membrane element, which includes in-plane nodal rotations, $v_{z}$, as degree of freedom. In this work Allman's approach is used. Allman's approach begins by selecting a quadratic form for the normal component of displacement, $\mathrm{U}_{\mathrm{n}}$, and a linear form for the tangential component of displacement, $\mathrm{U}_{\mathrm{t}}$, along each element edge $\mathrm{i}-\mathrm{j}$, Fig. 2.

$$
\begin{aligned}
& U_{n}=\left(1-\frac{\xi}{l_{i j}}\right) U_{n 1}+\left(\frac{\xi}{l_{i j}}\right) U_{n 2}+\frac{\xi}{l_{i j}}\left(1-\frac{\xi}{l_{i j}}\right)\left(\theta_{z 2}-\theta_{z 1}\right) \\
& U_{t}=\left(1-\frac{\xi}{l_{i j}}\right) U_{t 1}+\left(\frac{\xi}{l_{i j}}\right) U_{t 2}
\end{aligned}
$$

where $\varphi$ is the running distance from one end and $\left(\mathrm{U}_{\mathrm{n} 1}\right.$, $\left.\mathrm{U}_{\mathrm{t} 1}, \mathrm{v}_{\mathrm{z} 1}\right),\left(\mathrm{U}_{\mathrm{n} 2}, \mathrm{U}_{\mathrm{t} 2}, \mathrm{v}_{\mathrm{z} 2}\right)$ are the translational and rotational components displacements at each end of the edge.

As noted by Harder and Mac Neal [14] eqns. (9) and (10) can be used to eliminate the transitional displacements at the midpoint of the edge in favor of the degrees of freedom at the adjacent corner points so that, in this way, any eight-noded membrane quadrilateral can be converted into an element with corner translations and rotations as DOF's. Because of geometric complexity and large deformation in the postbuckling state of the laminate, a geometrically non-linear finiteelement analysis is performed.
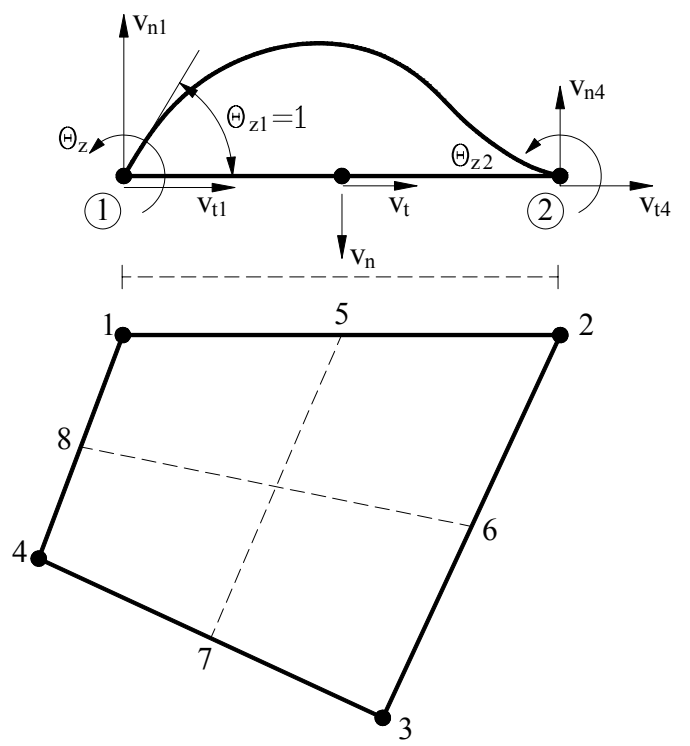

Figure 2. Membrane part of shell element

To solving of geometrically and material nonlinear problems, the load is applied as a sequence of sufficiently small increments so that the structure can be assumed to respond linearly during each increment.

For each increment of load, increments of displacements and corresponding increments of stress and strain are computed. These incremental quantities are used to compute various corrective stiffness matrices (variously termed geometric, initial stress, and initial strain matrices) which serve to take into account the deformed geometry of the structure. A subsequent increment of load is applied and the process is continued until the desired number of load increments has been applied. The net effect is to solve a sequence of linear problems wherein the stiffness properties are recomputed based on the current geometry prior to each load increment. The solution procedure takes the following mathematical form

$$
\left(\mathrm{K}_{\mathrm{L}}+\mathrm{K}_{\mathrm{NL}}\right)_{\mathrm{i}-1} \mathrm{DU} \mathrm{U}_{\mathrm{i}}=\mathrm{DQ}
$$

where:

$\mathrm{K}_{\mathrm{L}}$ is the linear stiffness matrix,

$\mathrm{K}_{\mathrm{NL}}$ is an incremental stiffness matrix based upon displacements at load step i-1,

$\Delta \mathrm{U}_{\mathrm{i}}$ is the increment of displacement due to the $\mathrm{i}-\mathrm{th}$ load increment,

$\Delta \mathrm{Q}$ is the increment of load applied.

\section{FAILURE CRITERION}

Initial failure of a layer within the laminate of a composite structure can be predicted by applying an appropriate failure criterion or first-ply failure theory. Failure modes in laminated composite panels are strongly dependent on ply orientation, loading direction and panel geometry. There are four basic modes of failure that occur in a laminate composite structures. These failure modes are: matrix cracking, fiber-matrix shear failure, fiber failure and delamination. Various first-ply failure theories are incorporated in the pre-, buckling and post-buckling failure analysis of the laminated fibrous composite structures. Failure criteria used with finite element results from the nonlinear postbuckling 
solutions qualitatively predict the load level and the location of local failures in the laminates that correspond to experimental results. A finite element computational procedure is incorporated for the first-ply failure analysis of laminated composite shells. The procedure is based on the higher-order shear deformation theory and tensor polynomal failure criterion

$$
\mathrm{F} . \mathrm{I}=F_{i} \sigma_{i}+F_{i j} \sigma_{i} \sigma_{j}+F_{i j k} \sigma_{i} \sigma_{j} \sigma_{k}+\ldots \geq 1
$$

where $\sigma_{\mathrm{i}}$ are the stress tensor components in material coordinates and $F_{\mathrm{i}}, F_{j}$ and $F_{i j k}$ are the components of the strength tensors. Most failure criterion are based on the stress state in a lamina. The Tsai-Wu criterion [15] was considered in this work in order to determine first-ply failure. Failure of axial compressed panel initiated near region with severe local bending gradients. Computation and experimental results indicate that local failures occurred in regions of large radial displacements. These local failures are associated with the brittle failure characteristics of the graphite-epoxy material system. The procedure of calculating the first-ply failure load of a laminated composite panels refers to calculating of stress and strains at all the nodes for each layer of laminate and then the maximum values of stress and strain are picked up. The failure loads for the weakest ply in the plate/shell are then calculated using various failure criteria using the iteration procedure. The increment in load level can be made suitable for predicting the failure load.

\subsection{Tsai- Wu criterion}

The Tsai-Wu failure criterion (also known as the Tsai$\mathrm{Wu}$ tensor polynomial theory) is commonly used for orthotropic materials with unequal tensile and compressive strengths. The failure index (F.I) according to this theory is computed using the following equation [22].

The coefficients $F_{i}$ and $F_{i j}$ in eqn (12) are functions of the unidirectional lamina strengths and are presented below for Tsai-Wu criteria $[15,22]$ :

$$
\mathrm{F}_{1} \sigma_{1}+\mathrm{F}_{11} \sigma_{1}{ }^{2}+\mathrm{F}_{2} \sigma_{2}+\mathrm{F}_{22} \sigma_{2}{ }^{2}+\mathrm{F}_{12} \sigma_{1} \sigma_{2}+\mathrm{F}_{66} \sigma_{6}{ }^{2} \leq 1
$$

where

$$
\begin{array}{lc}
F_{1}=X_{t}^{-1}-X_{c}^{-1}, & F_{2}=\left(Y_{t}^{-1}-Y_{c}^{-1}\right) \\
F_{11}=\left(X_{t} X_{c}\right)^{-1} & F_{22}=\left(Y_{t} Y_{c}\right)^{-1} \\
F_{12}=-\left(X_{t} X_{c} Y_{t} Y_{c}\right)^{\frac{1}{2}} & F_{66}=S^{-2}
\end{array}
$$

Here are: $X_{t}, X_{c}$ are the longitudinal tensile and compressive strengths, $Y_{t}, Y_{c}$ are the transverse tensile and compressive strength, $\mathrm{S}$ - rail shear strength. The Tsai-Wu failure criterion provides the mathematical relation for strength under combined stresses. According to the Tsai-Wu failure criterion, the failure of a lamina occurs if

$$
\text { F.I }>1
$$

The failure index in calculated in each ply of each element. In the ply where failure index is greater than 1 , the first-ply failure occurs, according to the Tsai-Wu criterion.

\section{NUMERICAL AND EXPERIMENTAL RESULTS}

A numerical analysis of critical and post critical behaviour of axially compressed composite panels was done applying 4-node shell finite elements (Q4-RT) and it was compared to the experimental results. Geometry, loads and boundary conditions are shown in Fig. 3. During the experiments the panel was clamped (c) along lateral edges where the loads were introduced and it was simply supported (ss) along its longitudinal edges (dashed lines). The finite elements mesh was formed for the whole panel and the boundary conditions were defined in the same way as it was done during the experiments (Fig. 4).

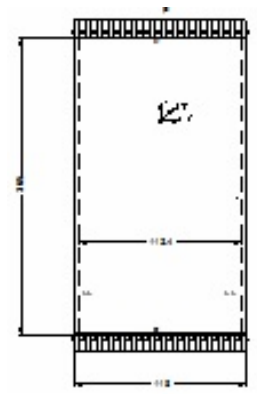

Figure 3. Axially compressed composite panel- Geometry and boundary conditions

An axially compresed composite panels are tested on SCHRENCK machine, Fig. 4. Composite panels are instaled in special tool in which two sides were simply supported (SS) and two sides were clamped (C) as shown in Figure 3.

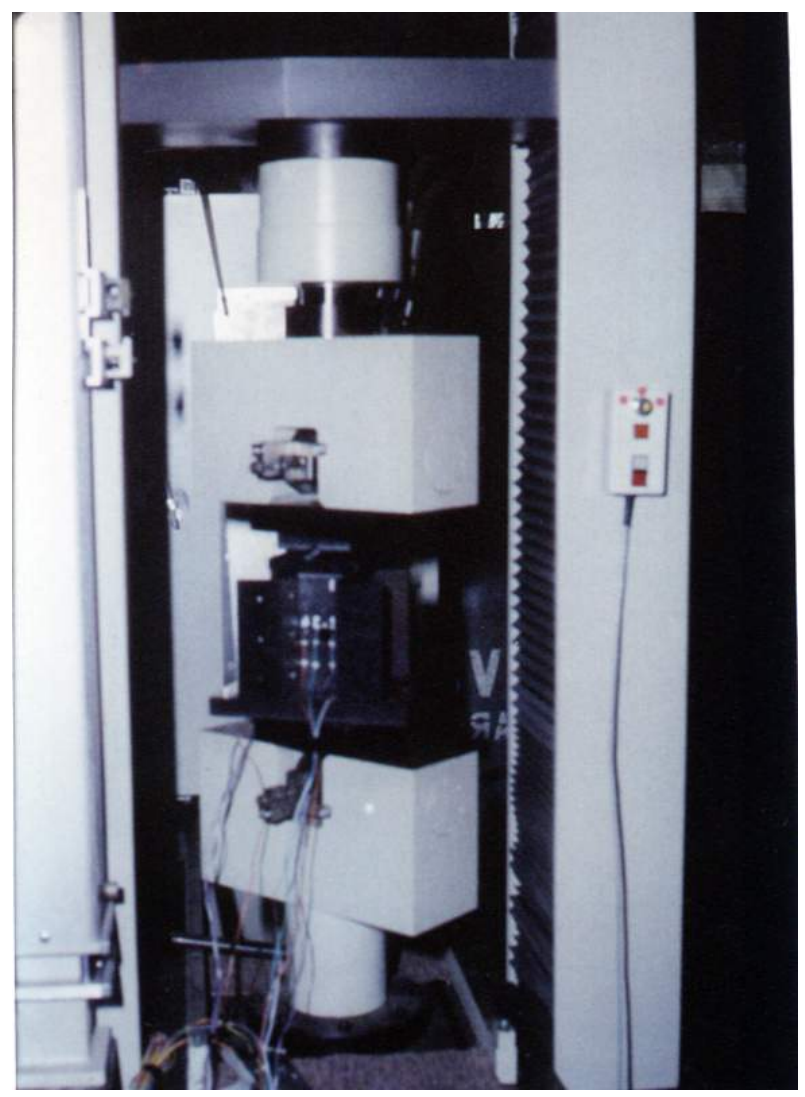

Fig. 4: Positions of Strain Gages and Transducers on Testing Specimen (Axially Compressed CFC Composite Panel)

Material of panel is CFC (Carbon Fiber Composite). Mechanical propeties of used CFC composite material are: $\mathrm{E}_{11}=142000[\mathrm{MPa}], \mathrm{E}_{22}=8500[\mathrm{MPa}], \mathrm{G}_{12}=5900$ $[\mathrm{MPa}], \mathrm{G}_{13}=5900[\mathrm{MPa}], \mathrm{G}_{23}=5900[\mathrm{MPa}], v_{12}=0.32$; 
$\mathrm{X}_{\mathrm{t}}=1369.5[\mathrm{MPa}], \mathrm{X}_{\mathrm{c}}=1077[\mathrm{MPa}], \mathrm{S}=92[\mathrm{MPa}] ; \mathrm{Y}_{\mathrm{t}}=$ $4.464[\mathrm{MPa}], \mathrm{Y}_{\mathrm{c}}=124[\mathrm{MPa}], \mathrm{t}_{\text {layer }}=0.125[\mathrm{~mm}]$. The finite element model of compresed layered composite panel is shown in Figure 5.

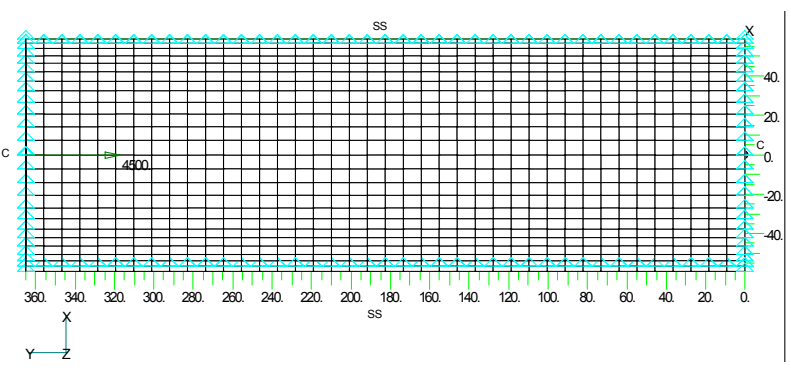

Figure 5. Axially compressed layered composite panelFinite element mesh

The analysis of critical and postcritical behaviour was done for three stacking sequences:
A- $\left[0^{\circ} / 90^{\circ} / \pm 45^{\circ}\right]_{2 \mathrm{~s}}$,
B- $\left[0^{\circ} / \pm 45^{\circ} / 90^{\circ}\right]_{2 \mathrm{~s}}$,
C- $\left[45^{\circ} / 0^{\circ} /-45^{\circ} / 90^{\circ}\right]_{2 \mathrm{~s}}$.

Besides the analysis of the critical and post critical behaviour of composite panels that was done using the nonlinear structural analysis the critical loads were determined applying the linear eigen-value problem. Both analyses were done for two types of material characteristics: in the cases of compression and extension of the used CFC material. Experimental and numerical results and the values of buckling loads $\mathrm{P}_{\mathrm{cr}}$ for all stacking sequences are given in Table 1.

Table 1: Buckling behaviour of axially compressed composite panels

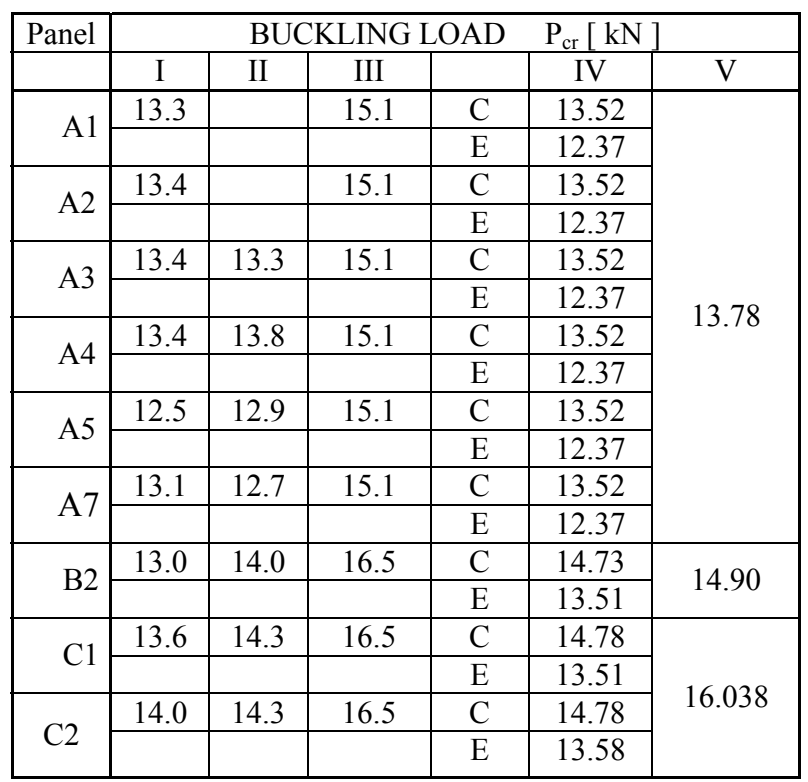

I - Experimental results: Buckling load determined from the Force-Axial displacement curve II - Experimental results: Buckling loads determined from membrane deformations

III - FINEL (FEM Software developed at Imperial College)

IV - Present numerical results: Buckling loads - FEM solutions obtained solving eigen-values
V - Present numerical results: Buckling loads - FEM solutions obtained from geometric nonlinear analysis (from the Load - Deflection curve)

E - Material characteristics - Tension

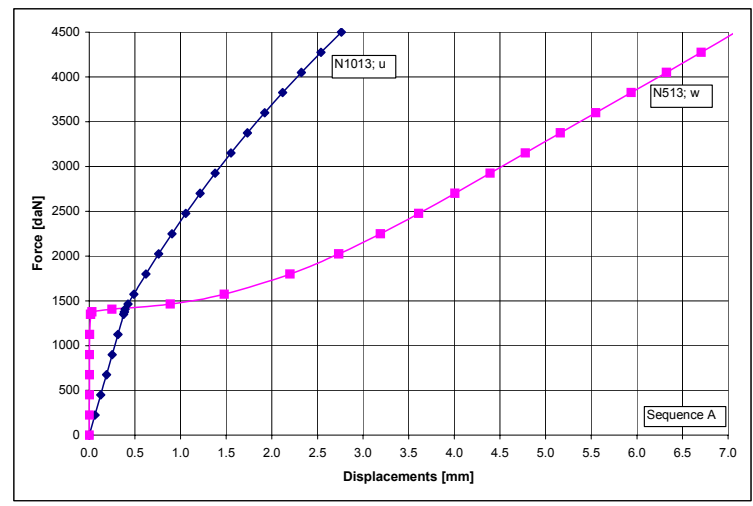

C - Material characteristics - Compression

Figure 6. Geometric Nonlinear Finite Element Analysis: P-u and P-w curves

( $\mathrm{u}, \mathrm{v}, \mathrm{w}-$ Displacements in $\mathrm{x}, \mathrm{y}, \mathrm{z}$ directions)

It is obvious from the Table 1 that the FEM results agree particularly well with the experiments in both cases: in linear and nonlinear analysis. It is even more interesting to underline the fact that the results obtained using the 4node shell finite element Q4-RT are closer to the experimental results than the results obtained applying 8node shell finite elements used by the FINEL software.

Besides the determination of the critical force $P_{c r}$ the analysis of the total post critical behaviour of the panels as well as the analysis of the initial failure - the levels of the load $\mathrm{P}_{\mathrm{f}}$ that correspond to the initial failure. Some of these results will be shown for the panel with the stacking sequence A and they are shown in Fig. 3. It is necessary to underline that the critical loads for the compressed panels can be determined from the Force Deflection w curves given in the Fig. 6: As it can be seen from that curve and the Table 1 a good agreement between numerical and experimental results was obtained.

The results of initial failure level are presented in Fig. 7 in the form of the distribution of initial failure coefficients F.I.

The value of the load $\mathrm{P}_{\mathrm{f}}$ corresponding to the initial failure is around $\mathbf{3 6} \mathbf{~ k N}$ and that is sufficiently above the critical load level $\left(\mathbf{P}_{\mathbf{f}} / \mathbf{P}_{\mathbf{c r}} \approx \mathbf{2 . 6}\right)$. Similarly high rates were obtained also for other panels and these rates are in accordance with the experiments.

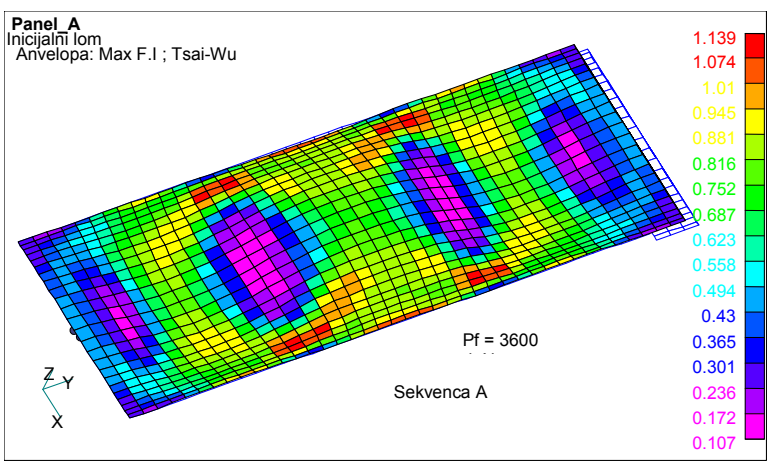

Fig. 7. Distribution of initial failure coefficients (F.I.) for the force $P_{f}$ 
As an illustration of the proposed computational method for the buckling and postbuckling analysis and for the initial failure analysis of layered composite structure here an axially compressed curved laminated panel is considered too. The panel geometry and boundary conditions of the panel supports are shown in Fig. 8.

The nonlinear response (P-w) of axially compressed curved composite panel in the case of stacking sequence $\mathrm{A}$ as well as the difference between two initial failure criterions is presented in Figs 9 and 10 and the numerical and experimental results including buckling and postbuckling behavior.

Two initial failure criterions are used: (1) Maximum strain criterion and (2) Tsai-Wu criterion. Table 2 shows comparisons of experimental and numerical results (nonlinear approach) for initial failure load $\mathrm{P}_{\mathrm{f}}$ and it can be seen that good agreement is obtained. From the practical point of view the numerically obtained results can be treated as excellent. It can be seen that in this case the Maximum strain criterion gave better results than the Tsai-Wu criterion.

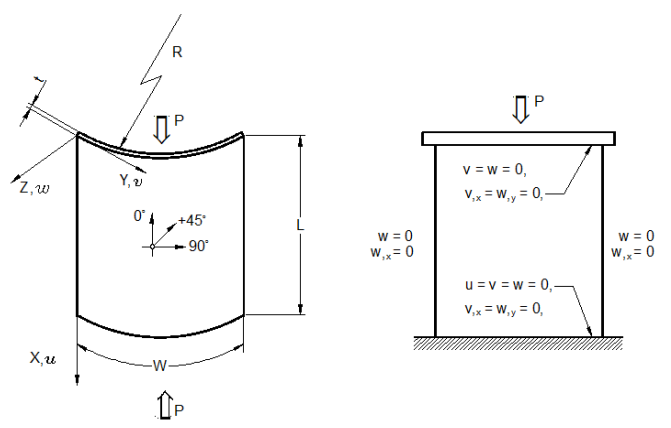

Fig. 8. Axially compressed curved composite panel (Stacking sequence: $A:[ \pm 45 / 0 / 90 / \pm 45 / 0 / 90]_{S}$ )

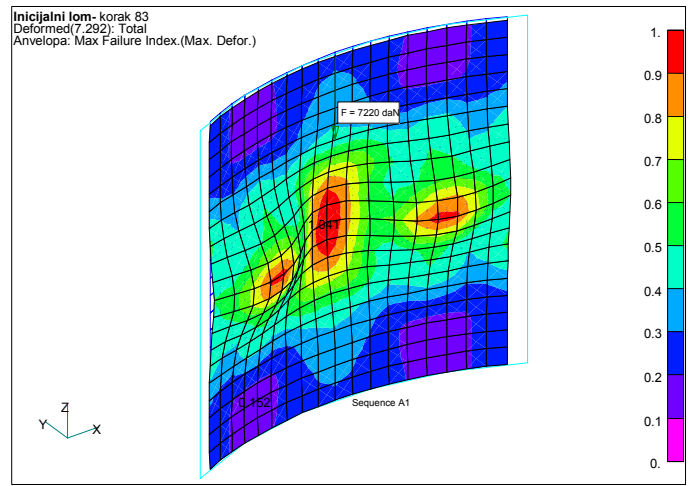

Fig. 9 Postbuckling response. Deformationns $\left(P_{f}=72200 N\right)$

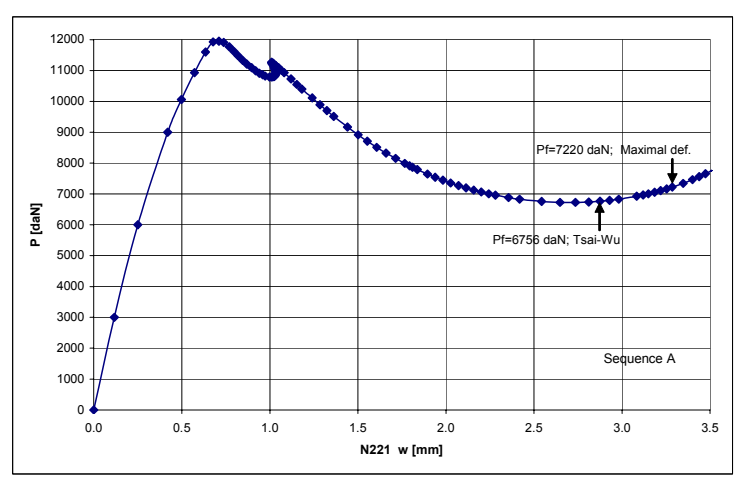

Fig. 10 - Postbuckling response. Axial load - radial displacement $(\mathrm{P}-\mathrm{w})$

\section{CONCLUSION}

The work presents numerical simulation of postbuckling behavior using finite element method to analyse the geometric nonlinear response of generally laminated flat und curved composite panels under axially compressed loads. The buckling and postbuckling behavior of axially compressed composite panels is investigated. The results of a numerical and experimental study to evaluate the initiation of damage in nonlinearity of the deformed flat and curved layered composite panels subjected to axial compression are presented. Experimental results of axially compressed panels carried out on SCHRENK servohidraulic system. A good agreement between numerical and experimental results is obtained. Failure criteria used with numerical results from the nonlinear postbuckling solutions qualitatively predict the load level and the location of first-ply failures in the layered composite panels that correspond to the experimental results The comparison of numerically obtained results with the experimental data shows that the used 4-node shell finite element can be successfully applied for the buckling and postbuckling analysis as well as for the initial failure analysis and for the prediction of the location of initial failure of compressed layered flat composite panels.

\section{REFERENCES}

[1] Altenbach, H., Altenbach, J. \& Kissing, W.: Mechanics of Composite Structural Elements, Ed. Springer, Berlin, 2004.

[2] Zweben C.H., Beaumont P.W.R. (Editors): Comprehensive Composite Materials II, 2nd Edition, Elsevier Ltd., Amsterdam, 2018.

[3] Beaumont P.W.R., Soutis C., Hodzic A. (Editors): Structural integrity and durability of advanced composites: Innovative modelling methods and intelligent design, Woodhead Publishing - Elsevier, Cambridge, 2015.

[4] Jawaid, M., Thariq, M. (Editors): Handbook Sustainable Composites for Aerospace Applications, Woodhead Publishing - Elsevier, Cambridge, 2018.

[5] Maksimovic, S., Improved geometrically nonlinear finite element analysis and failure of fiber reinforced composite laminates, Proc. Int. Symp. Brittle Matrix Composites 4, Warsaw, Sept. 13-15, Woodhead Publ., 1994.

[6] Thurley, G.J. \& Marshall, I.H., Buckling and Postbuckling of Composite Plates, Ed. Chapman \& Hall, London, 1995.

[7] Huyan X, Simitses G.J, Tabiei, A., Nonlinear analysis of imperfect metallic and laminated cylinders under bending loads, AIAA J, Vol. 34, No. 11; 2406-13, 1996.

[8] Bisagni, C., Numerical analysis and experimental correlation of composite shell buckling and postbuckling, Composites Part B: engineering, Vol. 31, No. 8, pp. 655-67, 2000.

[9] Reddy, J.N., Liu, C.F., A higher order shear deformation theory of laminated elastic shells, Int. J Eng Sci, Vol. 23, No. 3, pp. 319-30, 1985. 
[10]Riks, E., An incremental approach to solution to the solution of snapping and buckling problems, Int. J Solids and Structures, Vol. 15, pp 529-551, 1979.

[11] Maksimović M., Vasović I., Maksimović K., Maksimović S., Stamenković D., Crack growth analysis and residual life estimation of structural elements under mixed modes, 22nd European Conference on Fracture - ECF 22, Belgrade, Serbia, 26-31 August, 2018.

[12] Ružić, D, Maksimović, S., Milosavljević, D., Postbuckling response and failure analysis of layered composite structural components, Mechanics and Material Conference, 17-20, june. USA, 2003.

[13] Maksimović S., Maksimović K., Vasović I., Đurić M., Maksimović M., Residual life estimation of aircraft structural components under load spectrum, 8th International Scientific Conference on Defensive Technologies, OTEH 2018, Belgrade, Serbia, 11-12 Oktober, 2018.

[14]Allman, D.J., A compatible triangular element including vertex rotations for plane elasticity analysis, Comput. Struct., 19, 1-8, 1984.

[15] Mac Neal, R. H. and Harder, R. L., A refined fournoded membrane element with rotational degrees of freedom, Comput. Struct., 28, pp. 75-84, 1989.

[16] Tsai, S. W and Wu, E. M., A general theory of strength for anisotropic materials, J. comp. Mater, Vol. 5, 58-80, 1980.

[17] Maksimović, S., Some computational and experimental aspects of the optimal design process of composite structures, Int. J. of Composite Structures, Vol. 16. pp. 237-258, 1990.

[18] Ambarcumyan, S.A: Theory of Anisotropic Plates: Strength, Stability, and Vibrations, Hemispher Publishing, Washington, 1991.

[19] Boljanović, S., Maksimović, S., Carpinteri, A., Ćosić, M., Fatigue endurance design of plates with two semicircular edge notches and one quarterelliptical corner crack of through-the-thickness crack, International Journal of Fatigue, 127, pp. 4552, 2019.

[20] Petrašinović, N., Petrašinović, D., Rašuo B., Milković D.: Aircraft Duraluminum Wing Spar Fatigue Testing, FME Transactions, Vol. 45, No. 4, pp 531-536, 2017.

[21] Maksimović, M., Vasović, I., Maksimović, K., Trišović, N., Maksimović, S., Residual Life Estimation of Cracked Structural Components,
FME Transactions, pp. 124-128, 2018; doi: 10.5937/fmet1801124M.

[22] Maksimović, S. and Maksimović, K., Optimal Design Method for Weight Minimization of Composite Structures with Stability Constrains, J. Technical Diagnostics, Vol. 3, No. 2, 2004.

[23] Maksimovic, S., A simple and effective finite element for nonlinear analysis of layered composite shells using refined higher-order theory, Proc. 6th World Congress on FEM, Banff, Canada, Ed. J. Robinson, Robinson and Associates, 1990.

[24] Kastratović G.,Vidanović N., Grbović A.,Rašuo B., Approximate Determination of Stress Intensity Factor for Multiple Surface Cracks, FME Transactions, Vol.46, pp. 39-45, 2018.

[25] Vasić Z., Maksimović S., Georgijević D., Applied Integrated Design in Composite UAV Development, Appl Compos Mater, Vol. 25, No. 2, pp 221-236, 2018.

\section{АНАЛИЗА ГУБИТКА СТАБИЛНОСТИ И ИНИЦИЈАЛНИХ ОТКАЗА ПРИТИСНУТИХ КОМПОЗИТНИХ ПАНЕЛА ПРИМЕНОМ МКЕ}

\section{К. Максимовић, М. Максимовић И.В. Максимовић, Б. Рашуо, С. Максимовић}

У раду је разматран проблем критичног и посткритичног понашања вишеслојних композитних панела применом методе коначних елемената (МКЕ). Низ експеримената био је реализован у циљу поређења и верификације нумеричке резултате на бази МКЕ у домену стабилности и чврстоће композитне структуре. Комбинација геометријски нелинеарне анализе МКЕ засноване на Кармановој теорији и теорије смицања вишег реда (ТСВР) за формулацију коначног елемента су коришћене за анализу иницијалног лома као и посткритичног понашања вишеслојних композитних структура. За ту сврху је коришћен побољшани 4-чворни коначни елемент вишеслојне плоче/љуске. Формулација коначног елемента је заснована на теорији смицања вишег реда где сваки чвор има по осам степени слободе. Експлицитан метод је предложен за анализу критичног и посткритичног понашања вишеслојних композитних панела. Поређења између презентованих нумеричких и експерименталних резултата дају добра слагања. 